\title{
Plasmid analysis of Selenomonas ruminantium strains isolated from the rumen of fallow deer
}

\author{
I Vanat, P Pristas, $\mathrm{P}$ Javorsky \\ Institute of Animal Physiology, Slovak Academy of Sciences, Soltésovej 4-6, 04001 Kosice, Slovakia
}

Ten Selenomonas ruminantium strains isolated from the rumen of fallow deer were screened for the presence of plasmid DNA. All tested strains have been shown previously to possess specific restriction activities (Vanat et al, 1993, FEMS Microbiol Lett, 113, 129-132; Pristas et al, 1994, Arch Microbiol, 161, 439-441; Pristas et al, 1995, Gene, in press, and unpublished results). Eight strains have been found to contain plasmids that range in size from 1.4 $\mathrm{kbp}$ to greater than $35 \mathrm{kbp}$. No evidence of plasmid DNA was detected in two $S$. ruminantium strains 30D, 32D. Three tested strains 18D, 57D, 76D exhibiting the same restriction activity have been found to differ in plasmid contents. The possibility of plasmid coded R/M activities was examined. Because repeated subculturing of all three strains caused loss of plasmids without any significant decrease in restriction activities, it seems that sruRM genes are located on the host chromosomes.

A small $1.4 \mathrm{~kb}$ plasmid designated as pVPJ1 isolated from $S$. ruminantium strain 18D has been analysed in detail. pVPJ1 was cloned into the Pstl site of pKIL18 (Bernard et al, 1994, Gene, 148, 71-74) and the recombinant plasmid propagated in E. coli. Restriction analysis revealed unique restriction sites for Xbal, Sphl, Kpnl, Sspl, HindIII and Pstl. No restriction sites were found for BamHI, Sall, Pvul, Pvull, EcoRl and EcoRV.

Plasmid screening of $S$. ruminantium strains isolated from rumen of fallow deer confirmed the high frequency occurrence of plasmids in this bacterium reported previously (Martin and Dean, 1989, Appl Environ Microbiol, 55, 3035-3038; Zhang et al, 1991, Curr Microbiol, 22, 279-284; Fliegerova et al, 1994, Proc Soc Nutr Physiol, 3).

Further characterization of endogenous plasmids from hosts possessing specific R/M systems could create an effective cloning system for Selenomonas ruminantium and, help in solving survival problems for genetically modified bacteria in the rumen ecosystem. 